\title{
Regional Peculiarities of Business Relationships of the Russian Entrepreneur: Sociological Aspect
}

\author{
Ludmila Viktorovna Orlova ${ }^{1 *}$, Galina Pavlovna Gagarinskaya², Maria Albertovna \\ Mikheeva $^{3}$ and Anatoliy Dmitriyevich Yelyakov ${ }^{3}$ \\ 'Samara Academy of Municipal and State Management, Russia; Orlovalv313@mail.ru \\ 2Samara State Technical University, Russia \\ ${ }^{3}$ Samara State Universities of Economics, Russia
}

\begin{abstract}
The article presents the results of sociological research within the model of base system of business relations of the Russian entrepreneur. The investigation aims at analyzing current business relations and contacts providing business existence and development and the establishment of regional associations of entrepreneurs in the field of their regional business activity. Findings that allow us to describe the main peculiarities of the regional business space structure in modern Russia at the level of the entrepreneur's business relationships are analyzed.
\end{abstract}

Keywords: Entrepreneur's Business Space, Small and Medium-Sized Enterprises

\section{Introduction}

Today mainly economic sciences are involved into the investigation of entrepreneurship. However, understanding of the functions of entrepreneurial activity is changing in modern society. Social functions associated with the innovative development of society, the formation of entrepreneurial activity focused on self-realization, the development of the creative potential of individuals are advanced to the foreground. Business is becoming a more widespread phenomenon, which is developing in various spheres of society and attracts the attention of sociologists.

\section{Literature Review}

In the post-Soviet period such scientists as Z. T. Golenkova $^{1}$, A.V. Dakhin ${ }^{2}$, T. A. Zaslavskaya ${ }^{3}$, N. Ye. Tikhonova ${ }^{4}$, A. Yu. Chepurenko ${ }^{5}$, V. V. Radayev and O. I. Shkaratan ${ }^{6}$ and others are involved into the investigation of characteristics of entrepreneurs as a social group, the functional specificity of their activity, motivation, business, making their social portrait, revealing the socio-demographic, educational and other characteristics and specific personality traits as well.

The article also covers many issues of cooperation between small business with financial institutions, deformalization problems of interactions in the "authorities - business" system ${ }^{7,8}$, the problem of corruption $^{9,10}$. The review of the issues of small business development as structurally adaptive factor ensuring the transformation of Russian society is carried out ${ }^{11-}$ ${ }^{13}$. There is an interesting approach within which the motives that encourage people to be engaged in business stand out: the "forced" entrepreneurship and ideological entrepreneurship (entrepreneurship as an expression of ideology $)^{14}$. Developing the mentioned adaptational ("sociostructural" according to T.I. Zaslavskaya) concept of the origin and activity of entrepreneurs, researchers reveal the social sources, social forms of adaptation of small and medium-sized businesses representatives in a situation of adverse fluctuations in the business environment. In addition, there are many investigations about various aspects of the development of markets and competition in the world and in Russia, including

${ }^{*}$ Author for correspondence 
regional level ${ }^{3}$, describing the dynamics of the social environment in which entrepreneurs operate. These investigations relate Russia to global/general theoretical context of institutional changes in the market.

Investigations about the unification of entrepreneurs in business associations are carried out mainly in the organizational, legal and political aspects.

In the field of investigations of small and mediumsized enterprises the researches aimed at a holistic description of the social reality of small and medium-sized businesses in the regional dimension and social factors make the self-organization of small and medium business (establishment of associations, social associations of entrepreneurs, self-regulatory organizations) a form of social entrepreneurs' existence and to what extent this form of social existence becomes an element, the resource of conservation and development of regional business in a changing business environment are missing and therefore remain relevant

Some investigations relate to the resources of regional "networking relations" 14 , which an entrepreneur joins to maintain or to develop his/her business, and in which the correlation between the institutional trust and noninstitutional (personal) confidence ${ }^{15,16}$ is important.

\section{Research Methodology}

Sociological research in the form of a representative survey focused on the analysis of the regional business space structure for small and medium-sized businesses was conducted in 2010 in six cities of Russia. There were surveyed 300 people, 50 people in each region, using quota, target, representative sample, , which involved a survey of owners of enterprises, the share of small and medium-sized businesses were about the same (parent population is the number of small and medium-sized enterprises according to Rosstat (Federal Service for State Statistics), the quota is one-thousandth). Binary model of entrepreneur's business space, which consists of a private field and public field of business relations, was adopted as a working model.

The field of private business relations includes relations: "Business - the help of relatives", "Business the help of their national diaspora", "Business - the help of friends", "Business - the help of classmates", "Business - services for a bribe", "Business - services by "cashing" (shady financial transactions), "Business - the help of criminals". Here those types of business relationships are included, which are formed on an interpersonal basis, are based on the individual, interpersonal trust and do not suggest transparency, universal control by one or another organizations.

The field of public business relationship includes following relationships: "Business - municipal authorities", "Business - regional authorities", "Business - tax services", "Business -state supervision services", "Business - banking services", "Business - STSI" (road safety), "Business - Service of Ministry of Internal Affairs" (personal and business security), "Business - courts", "Business - recruiting services", "Business - transport agencies services", "Business - private security agencies services", "Business - pawnshop services", "Business - advertising and PR agencies services", "Business communication services", "Business - customs services", "Business - insurance companies services", "Business - the help of the public association of entrepreneurs", "Business -consulting organizations services", "Business - "business incubators" services, "Business -real estate agencies services", "Business - services of educational institutions", "Business -research institutions services", "Business - partnership with larger "players" in the segment"17.

\section{The Results of Sociological Research}

A model of the entrepreneur's basic business relations, relations in the structure of regional business space associated with the access of an entrepreneur to such business resources as administrative, financial, communicational and resources of fair resolution of disputes is the key model to the analysis of empirical data. The following two sets of relationships are accepted as basic (and competing) ones:

1) A Unit of the Public Sphere Relations: "Business - municipal authorities", "Business - regional authorities", "Business - banking services", "Business - courts", "Business - communication services", "Business - help the public association of entrepreneurs";

2) A Unit of the Private Sphere Relations: "Business -services for a bribe", "Business - services for laundering of money", "Business - the help of friends", "Business the help of relatives", "Business -the help of criminals".

In the framework of the model of base system of the 
entrepreneur's business relationships the data according to the assessment of the high-grade business relationships are presented in Table 1.

Table 1. T = The distribution of high assessment of business relations for the business preservation and development

\begin{tabular}{lc}
\hline Type of business relations & $\begin{array}{c}\text { Appreciation of the } \\
\text { importance (in \%) }\end{array}$ \\
\hline Business - banking services & 79.1 \\
Business - regional authorities & 76.8 \\
Business - the help of friends & 75.8 \\
Business - municipal authorities & 74.2 \\
Business - communication services & 73.2 \\
Business - the help of relatives & 69.9 \\
Business - courts & 52.6 \\
Business - help of the public asso- & 35.4 \\
ciation of entrepreneurs & \\
Business - services for bribery & 31.5 \\
Business - services for laundering & 30.8 \\
of money & \\
Business - the help of crime & 14.9 \\
\hline
\end{tabular}

The analysis of Table 1 suggests that the respondents' assessments of the importance of business relationships to ensure the survival or development of business are distributed among the relations in the private, nonformalized business field and in the field of public, institutional business communications.

This suggests the presence of shift of the Russian entrepreneur's business space in small and medium-sized businesses from the sphere of the public, institutional business relations to the sphere of private, personalized and formalized business relationships where the high importance of relations "Business - municipal authorities" (74.2\% of respondents) and "Business regional power" (76.8\% of respondents) compete with the high assessment of relations "Business - the help of friends" (75.8\%), "Business - the help of relatives" (69.9\%) and "Business - services for a bribe" (31.5\%). Estimates of the high importance of relations "Business - banking services" (79.1\%) compete with assessing the significance of relations "Business - services for laundering of money" (30.8\%), and estimates of the high importance of relations "Business - courts" (52 6\%) compete with the assessment of the high importance of relations "Business - the help crime" $(14.9 \%)^{17-19}$.
The resulting rating is divided into three groups: the first group includes the business relationship with the high importance for $50-80 \%$ of entrepreneurs; the second consists of business relationships with high relevance for 20-49\% of entrepreneurs and the third business relationships with significance for 1-19 \% of entrepreneurs.

Getting into the second subgroup, business relations with the business community $(35.4 \%)$, they compete in importance with bribery $(31.5 \%)$ and with the services for laundering of money (30.8\%) accordingly. We consider services for laundering of money as a direct consequence of corruption and partly of crime, since it is corruption and crime that create demand for unaccounted funds and thus stimulate the organization of illegal financial transactions. Therefore, it is bribery and crime that serve as key competitors to public organizations of entrepreneurs in the field of business relations.

The data show that more than $30 \%$ of entrepreneurs consider both bribery and the help of the public association of entrepreneurs as equivalent solutions to the problems of their business. If we take into account the prevalence of bribery, the fact that public entrepreneurs' organizations can make competition to the bribery, allows evaluating this fact positively. This viewpoint is also enhanced by the fact that the help of crime is considered important only by (!) $14.9 \%$ of entrepreneurs.

Thus, the current situation is that business associations of entrepreneurs make a real competition to the two most negative aspects of modern business - bribery and crime. It is crucial that both bribery and crime exist in noninstitutional, illegitimate field of business activity and non-governmental organizations competing with them present an institutional form. However, in comparison with the number of entrepreneurs who appreciate the importance of the help of friends (75.8\%) and family (69.9\%), the number of supporters of the high importance of the public association of entrepreneurs is less than a half. This means that from $39 \%$ to $45 \%$ of entrepreneurs clearly prefer, accordingly, the aid of relatives or friends to the public association of entrepreneurs. On the other hand, the help of public associations of entrepreneurs is a real alternative to the help of relatives or friends for $35 \%$ of entrepreneurs that is in a tough situation they are consider both assistance of the public association of entrepreneurs and the help of friends and relatives as equally important ${ }^{19}$. 
The percentage of entrepreneurs who recognize the high importance of relations "Business - the help of the public association of entrepreneurs", in comparison with the percentage of entrepreneurs, that value the importance of other (other than bribery, crime, laundering of money) network resources of their business space, allows us to more closely see the competitive field of activity of the public business associations.

Important qualitative characteristics of the structure of the regional business space for small and mediumsized businesses in the light of the importance to it public associations of entrepreneurs provide data about the level of satisfaction of any particular business relationships. The Satisfaction rates in the model of entrepreneurs' basic business relationships are shown in Table 2:

Table 2. The distribution of ratings of job satisfaction of business relations (in \% of number of entrepreneurs)

\begin{tabular}{lll}
\hline & Type of business relations & $\begin{array}{c}\text { Satisfaction } \\
(\%)\end{array}$ \\
\hline 1. & Business - the help of friends & 67.2 \\
2. & Business - the help of relatives & 64.6 \\
3. & Business - communication services & 54.6 \\
4. & Business - banking services & 48.0 \\
5. & Business - municipal authorities & 47.4 \\
6. & Business - regional authorities & 46.4 \\
7. & Business - courts & 33.4 \\
8. & Business - services for bribery & 22.8 \\
9. & $\quad$ Business - services for laundering of & 22.5 \\
& money & \\
10. & Business - the help of the public & 19.5 \\
11. & Business - the help of crime & 7.9 \\
\hline
\end{tabular}

The "satisfaction" in this case means that entrepreneurs are satisfied with how any particular relations can solve the problem of saving or developing their business, that certain business relationships have a high "efficiency", are effective in dealing with problems and entrepreneurs are satisfied with results.

Above all the data show the fact that the 'satisfaction' sphere is markedly shifted towards the sphere of private relations and, primarily, toward the satisfaction with the help of friends and relatives.

The satisfaction rating is also divided into three groups: the first group includes business relationships by which from $50 \%$ to $80 \%$ of entrepreneurs are satisfied; the second consists of business relationships that satisfy from $20 \%$ to $49 \%$ of entrepreneurs; the third - business relationships that satisfy from $1 \%$ to $20 \%$ of entrepreneurs. In the light of this approach the satisfaction of business relationships with public associations of entrepreneurs is a part of the third subgroup, because this assessment is shared by only $19.5 \%$ of entrepreneurs. The same group includes the crime, the satisfaction by the "services" of which $7.9 \%$ of entrepreneurs share ${ }^{2}$.

At the same time, corruption is estimated to be more effective than the aid of public association of entrepreneurs: $22.8 \%$ of entrepreneurs are satisfied with how this resource works (and 22.5\% of entrepreneurs are satisfied with "services" for laundering of money, accordingly). Thus, taking into account of these data, the competitive situation between public associations of entrepreneurs, corruption and crime looks more tense and dramatic.

\section{Discussion}

In general, these investigations confirm the presence of regional business space shift of small and mediumsized enterprises into the sphere of private relations. The difference between the number of entrepreneurs who appreciate the value of these business relationships and the number of entrepreneurs, who are satisfied with them, is more pronounced in the field of public, institutional business relationships and less in the private, noninstitutional business ties.

The generalized sociological model of formation of regional small and medium-sized enterprises reflects the social self-organization in the field of regional business activity. Spatial self-organization is seen as the process of forming a stable structure of the regional business space based on existing business relations of small and mediumsized businesses with regional resource sites.

Public associations of entrepreneurs are a resource place of regional space of entrepreneurs' business activity. The investigation showed that in 2009 the structure of the regional business space of small and mediumsized enterprises significantly shifted to private, noninstitutional business relationships leaving the social organization of entrepreneurs outside the circle of the most sought-after resource sites. Only $35.4 \%$ of entrepreneurs note the high importance of public business organizations to solve business issues. In comparison to 
the significance assessments of other resource sites based on any particular forms of self-organization (the help of friends $-75.8 \%$, support of relatives $-69.9 \%$ ), the value of the public association reflects its peripheral character. The above-mentioned resource spaces compete with the public association for a place in the structure of the regional business space, but the most fundamental rival is the crime social networks whose importance for the business $14.9 \%$ of entrepreneurs note and semi-criminal corruption networks, the importance of which $31.5 \%$ of entrepreneurs mention as well ${ }^{2}$.

The main conceptual provisions of the model considered are as follows.

The entrepreneur's regional business space has a dual structure, including the public sphere and private sphere of business relations. Business relations of an entrepreneur with public organization of entrepreneurs belong to the sphere of social relations, as they are the institutional form of entrepreneurs' access to network resources of their community.

The public organization of entrepreneurs as an institutional form of access to a network resource is characterized by legality, transparency, organizational and functional adaptability, observance of the principle of actors' equal rights.

\section{Conclusions}

As shown by the data of sociological research, an important regional business space gives a representative of small and medium-sized enterprise the opportunity to select different types of private network resources (interpersonal communication), among which family ties, friendship and criminal connections are of the greatest significance. They are characterized by extra-legacy or illegacy, privacy, organizational and functional archaic nature, more or less rigid hierarchy of inequality. Nevertheless, all these resources have a competitive advantage to each other and similar meaningful characteristics primarily in that they can provide a wide range of entrepreneur "services".

Special attention should be paid to such opportunities of network systems mentioned as a fair solution of disputes and the establishment of the entrepreneur's business behavior standards. The fact is that these aspects of network systems compete with specialized social institutions - the courts, the legislative and executive institutions of government. Thus, in the structure of the regional business space social organizations meaningfully intersect with the functioning of the two groups of resource locations. On the one hand, they are competing with related, friendly and criminal networks. Here we use the word 'competing' to determine the functional intersection because social alternative forms of access to resources have opposite characteristics of transparency, adaptability and institutionality. On the other hand, public associations complement the activity of the courts and the legislative and executive institutions. 'Complement' means that associations have similar institutional attributes that are in a state of becoming, resources for the resolution of disputes and the establishment of standards of behavior of entrepreneurs (business ethics), but take a substantial niche: they cannot stand the verdict, but may prevent conflicts and protect against external challenges; they do not claim legislative acts, but may take the professional code of ethics, professional and others norms (this is especially characteristic of the self-regulatory organizations).

\section{References}

1. Golenkova ZT. Transformatsiyasotsialnoystrukturyistratifikatsiyarossiyskogoobshchestva [The Transformation of the Social Structure and Stratification of the Russian Society]. In: Golenkova ZT, editor. Moscow: Institute of Sociology RAS; 1996; 469. [in Russian]

2. Dakhin AV. (Samoorganizatsiyamalogoisrednegobiznesa v Rossii (analizznacheniyaregionalnykhobshchestvennykhorganizatsiypredprinimateley $\mathrm{v}$ pole ikhdelovoyaktivnosti) [Self-Organization of Small and Medium Business in Russia (The Analysis of the Value of Regional Public Organizations of Entrepreneurs in the Field of their Business Activity)]. Governance. 2009; 11:4-11. [in Russian]

3. Zaslavskaya TI. Sotsiostrukturnyyaspekttransformatsiirossiyskogoobshchestva [Sociostructural Aspect of the Transformation of Russian Society]. Sotsys. 2001; 8:3-11. [in Russian]

4. Tikhonova NE, Mareeva SV.Sredniyklass: teoriyairealnost [Middle Class: Theory and Reality]. Moscow: Alpha-M; 2009. [in Russian]

5. Chepurenko AY. Razvitierossiyskogochastnogopredprinimatelstva v mezhstranovomsopostavlenii [Development of the Russian Private Business in Cross-Country Comparison]. Problems of Economics. 2008; 8:91-107. [in Russian]

6. Radaev VV, Shkaratan OI. Sotsialnayastratifikatsiya [Social Stratification]. Moscow: Aspect Press; 1996 [ in Russian]

7. Chirikova AE. Vzaimodeystvievlastiibiznesa v realizatsiisotsialnoypolitiki: Regionalnayaproektsiya [The Interaction between Business and Government in the Implemen- 
tation of Social Policy: a Regional Projection]. Moscow: Independent Institute for Social Policy; 2007. [in Russian]

8. Kovalyov VA, Krotov PP. Regionalnayavlastibiznes: problemyvzaimodeystviya [Regional Authorities and Business: Problems of Interaction]. Sotsys. 2004; 7

9. Borisov VA. Sotsialnoepartnyorstvo v Rossii: spetsifikailipodmenaponyatiy? [Social Partnership in Russia: Specific or Substitution of Concepts?] Sotsys. 2001; 5. [in Russian].

10. Perov VI. Razvitiemalogobiznesa v regionei ego vzaimodeystvie s krupnym [Development of Small Business in the Region and its Interaction with Major Business]. The State Service. 2007; 4 [in Russian].

11. Radaev VV. Ekonomicheskayasotsiologiya [Economic Sociology]. Moscow: Aspect Press; 2000. [in Russian].

12. Nefedov VN. Politicheskiy dialog mezhdumalymbiznesomigosudarstvennymistrukturami: tekushchayasituatsiyaiperspektivy [Political dialogue between small business and government agencies: current situation and prospects]. Nizhny Novgorod; 2002 [in Russian].

13. Granovetter M. Economic Action and Social Structure: The Problem of Embeddedness. American Journal of Sociology. 1985; 91(2):481-510.
14. Velter F, Kautonen T, Chepurenko A, Malieva E. Strukturyupravleniyasetevymisoobshchestvamimalykhpredpriyatiyiroldoveriya: germano-rossiyskoesopostavlenie [Management Framework Network Communities of Small Enterprises and the Role of Trust: German-Russian Comparison]. Economic Sociology. 2004; 5(2). [in Russian].

15. March J, Olsen J. The New Institutionalism: Organizational Factors in Political Life. Stanford University; 1983. [in Russian].

16. Rocman B. The New Institutionalism and Old Institutions. New Perspectives on American Politics. In: Dodd L, Jilson C, editors. Washington, DC: CQ Press; 1994.

17. Orlova LV. Sociological Model of Business Space of a Russian Businessman. Part 1. Human Resources and Intellectual Resources Management in Russia. 2014; 6(56). Moscow: INFRA-M, doi: 10.12737.

18. Orlova LV. Structure of Regional Business Space in Modern Russia: Sociological Aspect. Australian Journal of Scientific Research. Adelaide: Adelaide University Press; 2014; 1(5):905-11.

19. Orlova LV. The structure of the regional business space of modern Russia. Japanese Educational and Scientific Review, Tokyo University Press; 2015; 1(9) (Jan-Jun); 473-8. 